\title{
Improving the Quality of Rubber Plants in Bagged Nurseries by the Use of Compost-Based Culture Substrates
}

\author{
Jean Lopez Essehi ${ }^{*}$, Eric Francis Soumahin' ${ }^{2}$ Guy Fernand Yao1, \\ Samuel Obouayeba ${ }^{3}$, Albert Yao-Kouamé ${ }^{4}$
}

${ }^{1}$ National Agricultural of Research Centre, Food Crop Research Station, Soil Water and Plant Central Laboratory, Bouaké, Côte d'Ivoire

${ }^{2}$ University Jean Lorougnon Guédé, Training and Research Unit of Agroforestry, Laboratory of Physiology and Plant Pathology, Daloa, Côte d'Ivoire

${ }^{3}$ National Agricultural of Research Centre, Research Station of Bimbresso, Hevea Program, Bimbresso, Côte d'Ivoire ${ }^{4}$ University Félix Houphouët-Boigny, Training and Research Unit of Earth Sciences and Mineral Resources, Department of Soil Sciences, Abidjan, Côte d'Ivoire

Email: *lopezessehi@gmail.com

How to cite this paper: Essehi, J.L., Soumahin, E.F., Yao, G.F., Obouayeba, S. and Yao-Kouamé, A. (2021) Improving the Quality of Rubber Plants in Bagged Nurseries by the Use of Compost-Based Culture Substrates. Open Journal of Soil Science, 11, 567-585. https://doi.org/10.4236/ojss.2021.1111028

Received: October 4, 2021

Accepted: November 26, 2021

Published: November 29, 2021

Copyright $\odot 2021$ by author(s) and Scientific Research Publishing Inc. This work is licensed under the Creative Commons Attribution International License (CC BY 4.0).

http://creativecommons.org/licenses/by/4.0/ Open Access

\begin{abstract}
The decrease of fertility soils, the rarity of quality potting soil used to fill nursery bags, the high cost of chemical fertilisers and the problems associated with their use are leading planters and rubber nurserymen in developing and/or expanding areas to look for alternative and sustainable fertilization. In this perspective, a trial was carried out at Research Station of CNRA-Bimbresso and in a farmer's environment in order to evaluate the agronomic quality of compost made from chicken droppings and dry Panicum maximum straw to improve the growth of rubber plants in bagged nurseries. Mixtures based on potting soil and/or compost in different proportions were prepared. The follow-up of the trial focused on determination of the physico-chemical characteristics of the soils, measurement of the parameters of vegetative growth and the grafting success rate evaluation of rubber plants in nursery. The results obtained show that compost-based crop substrates increase soil organic matter, nitrogen, exchangeable bases, etc., in proportion to the doses applied. For the $\mathrm{pH}$, the application of compost resulted in a reduction in soil acidity of about 1.3 unit compared to the initial values at the two study sites. The vegetative behaviour of the rubber plants also shows that qualitative (height and collar diameter) and quantitative (grafting success rate) improvements were recorded in the plants raised in compost-based substrates. The production of rubber plants in bagged nurseries was optimal with compost doses of $27 \mathrm{t} \cdot \mathrm{ha}^{-1}$ (at Bimbresso, in the southeast) and $27 \mathrm{t} \cdot \mathrm{ha}^{-1}$ combined with fractionated ap-
\end{abstract}


plication of urea (at Kimoukro, in the centre), which under the conditions of the present study may be the recommended doses on rubber plants in bagged nurseries at Côte d'Ivoire.

\section{Keywords}

Compost, Soils Parameters, Vegetative Growth, Hevea brasiliensis, Côte d'Ivoire

\section{Introduction}

In the context of crop diversification, rubber cultivation in Côte d'Ivoire is of considerable economic interest and has become increasingly popular among many populations in recent years. This plant has been introduced by Agro-industrial Rubber Companies in the years fifty [1]. Côte d'Ivoire, formerly $6^{\text {th }}$ in the world, has jumped 3 points. It thus becomes the only non-Asian country in the international rubber top 5 behind Thailand $\left(1^{\text {st }}\right)$, Indonesia $\left(2^{\text {nd }}\right)$ and Vietnam $\left(3^{\text {rd }}\right)$. This position was acquired thanks to its 850,000 tonnes of rubber produced in 2019 , an increase of $13 \%$ compared to the previous year [2].

The prodigious development was boosted, on the one hand, by the improvement in the purchase price of rubber at the edge of the field, and on the other hand, by the subsidy for the production of rubber plants by Fonds de Développement pour l'Hévéa (FDH), which is Hevea Development funds. Also, many studies carried out in the field of genetic improvement and latex harvesting technologies [3] [4] [5] [6] have contributed to this. As a result, Côte d'Ivoire has one of the highest yields in the world, at $1650 \mathrm{~kg} \cdot \mathrm{ha}^{-1} \cdot \mathrm{year}^{-1}$ [7]. It is such a performance that the country intends to consolidate in a context of strong demand for natural rubber.

This performance could however, be hampered by a number of concerns, in particular land and parasite pressure in traditional rubber tree areas, the aging of the verger and the low level of adoption of the technical itineraries. Also, note that the development plan for the rubber industries envisages production of about 2 million tonnes of natural rubber over the next five years, to consolidate its leadership in Africa.

In order to achieve this objective and to meet the ever-increasing demand for natural rubber, two strategies can be adopted. The first is to improve the productivity of rubber trees in traditional growing areas by optimising latex harvesting system of rubber trees, appropriate replanting techniques, selecting clones that are more efficient and better adapted to local environmental conditions and by good plantation management, etc. The second strategy consists of extending the rubber plantations areas to non-traditional areas, described as marginal. Moreover, any replanting or extension of rubber tree plantation areas necessarily starts from nurseries, which occupying a pivotal position in the production cycle of vegetal material, is at origin of any plantation creation project.

The rubber plants in bagged nurseries remain the only effective means of ob- 
taining quality plants material that guarantees the profitable and sustainable exploitation of rubber tree plantations. The high demand for planting material, linked to interest in rubber tree cultivation over the last decade, has shown the need for rubber plants to shorten the production time of planting material in the nursery.

As a result, the lack of vigour of the plant material produced is one of the causes of high mortality after transplanting. The considerable loss of planting material in the nursery results in heterogeneity in tree growth, induced by rubber trees replacements and consequently a significant reduction in the number of exploitable trees. Also, Mougo [8] has revealed that losses of rubber plants in nurseries could reach more than $75 \%$ before grafting, $53 \%$ of which is due to the type of vegetal material and crop substrates.

For materials that are accessible and meet the requirements of plant growth, several studies have looked into the recycling of organic waste [9]-[15]. In fact, the use of composting organic waste is a potential choice to be developed for interesting agronomic and environmental reasons. In the context of organic waste recovery using the pit composting technique, the aim of this study is to evaluate on the one hand the effect of composts on plant growth and on the other hand its effect on the soil quality improvement.

\section{Material and Methods}

\subsection{Study Environment}

The study was carried out at the experimental site of the CNRA-Bimbresso Research Station, in the southeast (N05 $18^{\prime} 45.2^{\prime \prime}$ and W004 $\left.{ }^{\circ} 9^{\prime} 18.9^{\prime \prime}\right)$ and the Kimoukro site, in a farming area (N06 $33^{\prime} 0^{\prime \prime}$ and W005 $\left.15^{\prime} 0^{\prime \prime}\right)$, in the centre of Côte d'Ivoire. Climates, in the southeast of humid subtropical type and in the centre of transitional equatorial type, are characterized by four seasons clearly differentiated by their bimodal rainfall regime [16] [17]. Average annual rainfall is estimated at $1.800 \mathrm{~mm}$ in the southeast and $1.200 \mathrm{~mm}$ in centre of Côte d'Ivoire [17] [18].

The soil at Bimbresso site, belonging to the Ferralsols class [19] is deep and tertiary sandy. It characterized by a clay-sand texture in the surface horizons. The pedological study carried out at Kimoukro site showed that the profile soil belongs to Cambisol class [19]. Table 1 shows the physico-chemical properties of these soils before the trial was implemented.

\subsection{Plant Material}

As the choice of rootstock is an important element in the success of grafting [20], the plant material used consists of about one month old GT1 clone rubber tree seedling. The clone GT1 from Indonesia is considered the best rootstock and it is the reference one in Côte d'Ivoire.

\subsection{Fertilizer Material (Compost and Mineral Fertilizer)}

The compost used was obtained by recycling chicken droppings and dry straw 
from Panicum maximum composted in a pit for 18 weeks. The contents of the pit were turned over once every 4 weeks to ensure good aeration and to reduce anaerobic fermentation. The physico-chemical characteristics of this compost are mentioned in Table 2. Urea $\left[\mathrm{CO}\left(\mathrm{NH}_{2}\right)_{2}\right]$ at $46 \% \mathrm{~N}$ was used for fertilization of rubber plants in bagged nurseries.

\subsection{Soils, Gauges and Crop Substrates Preparation}

The study plots, with an area of $300 \mathrm{~m}^{2}(20 \mathrm{~m} \times 15 \mathrm{~m})$, were manually cleared.

Table 1. Physical and chemical properties of soils before the implementation of the trial

\begin{tabular}{|c|c|c|c|c|}
\hline & & \multirow{2}{*}{ Units } & \multicolumn{2}{|c|}{ Data values of sites } \\
\hline & & & Bimbresso & Kimoukro \\
\hline Texture & & & Sc & Slc \\
\hline \multirow[t]{5}{*}{ Particles size } & Clay $(0-2 \mu)$ & $\%$ & 16.00 & 13.50 \\
\hline & fine Loam $(2-20 \mu)$ & $\%$ & 3.35 & 15.00 \\
\hline & coarse Loam $(20-50 \mu)$ & $\%$ & 5.60 & 24.80 \\
\hline & fine Sand $(50-200 \mu)$ & $\%$ & 22.50 & 43.15 \\
\hline & coarse Sand $(200-2000 \mu)$ & $\%$ & 52.55 & 3.55 \\
\hline Soil acidity & $\mathrm{pH}\left(\mathrm{H}_{2} \mathrm{O}\right)$ & - & 5.40 & 6.40 \\
\hline \multirow[t]{4}{*}{ Organic matter } & C (organic Carbon) & $\%$ & 1.17 & 2.61 \\
\hline & $\mathrm{N}$ (total Nitrogen) & $\%$ & 0.11 & 0.17 \\
\hline & $\mathrm{C} / \mathrm{N}$ & - & 10.64 & 15.35 \\
\hline & Organic matter & $\%$ & 2.01 & 4.49 \\
\hline Phosphorus & available & ppm & 75 & 175 \\
\hline \multirow[t]{7}{*}{ Absorption Complex } & $\mathrm{Ca}^{2+}$ & $\mathrm{cmol} \cdot \mathrm{kg}^{-1}$ & 0.41 & 4.70 \\
\hline & $\mathrm{Mg}^{2+}$ & $\mathrm{cmol} \cdot \mathrm{kg}^{-1}$ & 0.29 & 2.06 \\
\hline & $\mathrm{K}^{+}$ & $\mathrm{cmol} \cdot \mathrm{kg}^{-1}$ & 0.02 & 0.18 \\
\hline & $\mathrm{Na}^{+}$ & $\mathrm{cmol} \cdot \mathrm{kg}^{-1}$ & 0.06 & 0.04 \\
\hline & CEC & $\mathrm{cmol} \cdot \mathrm{kg}^{-1}$ & 8.00 & 13.25 \\
\hline & Sum of bases (SBE) & $\mathrm{cmol} \cdot \mathrm{kg}^{-1}$ & 0.78 & 7.04 \\
\hline & Saturation (V) & $\%$ & 9.75 & 53.13 \\
\hline
\end{tabular}

Sc: Sandy-clay; Slc: Sandy-loamy-clay.

Table 2. Physico-chemical characteristics of the compost used.

\begin{tabular}{ccccccccccc}
\hline \multicolumn{3}{c}{ Physico-chemical properties } & \multicolumn{8}{c}{ Chemical properties (ms\%) } \\
\hline $\mathrm{pH}$ & $\% \mathrm{H}$ & $\varnothing \leq 10 \mathrm{~mm}$ & $\mathrm{C}$ & $\mathrm{N}$ & $\mathrm{C} / \mathrm{N}$ & $\mathrm{P}$ & $\mathrm{K}$ & $\mathrm{Ca}$ & $\mathrm{Mg}$ \\
\hline 7.2 & 30.16 & 95.54 & 7.72 & 0.64 & 12.06 & 0.68 & 0.39 & 1.99 & 0.87 \\
\hline
\end{tabular}

$\% \mathrm{H}$ : relative humidity; $\varnothing$ : proportions of fine elements; $\mathrm{ms} \%$ : percentage of dry matter. 
Then, they were materialised by placing gauges on the ground with the help of stakes.

Eight (8) gauges were opened to obtain $0.2 \mathrm{~m}$ width; $4 \mathrm{~m}$ length and $0.2 \mathrm{~m}$ depth. The distance between two gauges was $1 \mathrm{~m}$. The soil, placed on the same side when the gauges were dug, was used as a growing medium, mixed or not with compost used, to fill the bags. These bags, measuring $40 \mathrm{~cm}$ long and $10 \mathrm{~cm}$ wide, were placed $2 / 3$ of the height and laid out in the gauges in discontinuous tetrads, with one gauge forming a micro-plot.

\subsection{Establishment of Germoir and Planting of Rubber Tree Seedlings}

The establishment of rubber tree nursery necessarily requires a germoir. It is made up of beds of one (1) square metre that can contain up to 1000 seeds. This strip consisted of a light medium about five to $10 \mathrm{~cm}$ thick of sand and was covered by a shady area made up of oil palm stalks. The seeds used were those of the GT1 clone. 30 days after sowing, the seedlings obtained were transplanted in the bags.

\subsection{Experimental Design and Trial Management}

The trial was conducted with a randomised complete block design. Fertilization was main factor and the dose of the compost, the second one with 6 modalities (Table 3). Each treatment, repeated 3 times, consists of 40 plants. The number of effective plants was 720 out of 1152 plants. Urea (46\% of nitrogen) was applied in three applications. The first treatment was applied as a background fertilizer. The second one occured at the stage of the second mature leaf and the last one was performed one month after the second one.

The urea was dissolved in water ( $50 \mathrm{~mL}$ of water per plant) and brought to plants. However, the compost applications were done in one go (when filling the bags). The estimated water requirements of rubber plants in the nursery are 120

Table 3. Doses of mineral fertilizer and compost treatments.

\begin{tabular}{|c|c|c|c|c|}
\hline \multirow{2}{*}{$\begin{array}{l}\text { Substrates } \\
\text { of culture }\end{array}$} & \multicolumn{3}{|c|}{ Mineral fertilizer $\left(\mathrm{kg} \mathrm{ha}^{-1}\right)$} & \multirow{2}{*}{$\begin{array}{c}\text { Compost treatments } \\
\left(\mathrm{t} \cdot \mathrm{ha}^{-1}\right)\end{array}$} \\
\hline & Background fertilizer & $2^{\text {nd }}$ leaf stage mature & $3^{\text {rd }}$ leaf stage mature & \\
\hline S1 (no fertilizer) & 0 & 0 & 0 & 0 \\
\hline S2 & 360 (4 g per plant) & 630 (7 g per plant) & 990 (11 g per plant) & 0 \\
\hline S3 & 0 & 0 & 0 & 27 (300 g/plant) \\
\hline S4 & 0 & 0 & 0 & $54(600 \mathrm{~g} /$ plant $)$ \\
\hline S5 & 180 (2 g per plant $)$ & 315 (3.5 g per plant) & 495 (5.5 g per plant) & 27 (300 g per plant) \\
\hline S6 & 90 (1 g per plant) & 157.5 (1.75 g per plant) & 247.5 (2.75 g per plant) & 54 (600 g per plant) \\
\hline
\end{tabular}

S1: control, no fertilizer; S2: fractional application of urea; S3. S4. S5 and S6: composts treatments and/or fractional application of urea substrates. 
$\mathrm{mm}$ of water per month, in dry conditions. The plants were watered manually with a $15 \mathrm{~L}$ watering can at the least hot hours of the day (early morning or afternoon). Watering was done three times a week at a rate of $15 \mathrm{~L}$ of water per 100 plants. After transplanting, weeding of the nurseries was made on demand with the daba and the machete.

\subsection{Measurements and Observations}

\subsubsection{Soil Parameters}

On each trial, a series of samples is collected by treatment from the prepared crop substrates. These samples were dried in the open air for 72 hours to a week, according to moisture content of the sample. After drying, the samples were broken up by hand and sieved with a $2 \mathrm{~mm}$ grid sieve to obtain fine earth for laboratory analysis. These analyses consisted in determining $\mathrm{pH}\left(\mathrm{H}_{2} \mathrm{O}\right)$, Organic Carbon (C), total Nitrogen (N), available Phosphorus (P), Exchangeable bases $\left(\mathrm{K}^{+}, \mathrm{Ca}^{2+}, \mathrm{Mg}^{2+}, \mathrm{Na}^{+}\right)$, as well as cation exchange capacity (CEC) according to standard methods and procedures.

\subsubsection{Measurement of Vegetative Growth Parameters}

In order to evaluate the performance of crop substrates elaborated, measurements of aerial vegetative growth parameters of the rubber plants in bagged nurseries were collected monthly during the nursery cycle. The total height $\mathrm{H}(\mathrm{mm})$ of the plant was measured from collar (at ground level) to apical end of the plant using a graduated ruler. The collar diameter $(\mathrm{mm})$ was determined at $5 \mathrm{~cm}$ from the ground using a Stainless Hardened calliper. Average monthly increases in height $(\Delta H)$ and collar diameter $(\Delta C)$ were obtained according to following formula:

$$
\Delta(H, C)=M \alpha-M \tau
$$

where $M \alpha$ and $M \tau$, expressed in $\mathrm{mm} \cdot \mathrm{month}^{-1}$, are two measurements carried out at successive observations stages.

The average monthly growth was used to determine the growth gain expressed as a percentage of reference or control substrate (S1).

$$
\operatorname{Gain}(\%)=\frac{\Delta(H, C)_{\text {substrate }}}{\Delta(H, C)_{\text {control }}} \times 100
$$

$\Delta(H, C)_{\text {substrate }}$ : Average growth $(H, C)$ of substrate $(2,3,4,5$ and 6);

$\Delta(H, C)_{\text {control }}$ : Average growth $(H, C)$ of control substrate (S1).

\subsection{Production of Rubber Plants in Bagged Nurseries}

The most common method of reproduction for the establishment of plantations is vegetative propagation. This multiplication is performed using several techniques, but it is the dormant eye patch grafting which is the most common in modern rubber plantations, as it allows much more homogeneous planted areas to be obtained, from which future rubber production can be accurately estimated [21]. 
After the grafts are taken from the woodlot, the best graft protectors are also selected. These are healthy plants with a diameter of more than $10 \mathrm{~mm}$ at 6 months [21] [22]. The graft starts from the opening of a window $5 \mathrm{~cm}$ from the collar on rootstock by means of a gruffer, proceeding by means of two vertical incisions $5 \mathrm{~cm}$ long, 1.5 to $2.5 \mathrm{~cm}$ distant. A strip of bark is thus formed and completely removed. Then, a graft, previously taken from the grafted wood using the grafting tool, is inserted under the tongue that has been detached from rootstock. The assembly is then bound with a transparent polyethylene tie. The control of the successful grafting takes place every week after graft and unbending, this takes place 21 days after grafting. The last control takes place 10 days after the unbending. The Grafting Success Rate (TxR), determined by carrying out a grafting success verification was:

$$
\operatorname{TxR}(\%)=\frac{\mathrm{NbPtR}}{\mathrm{NbPtP}} \times 100
$$

TxR (\%): Graft success rate;

NbPtR: Number of rubber plants in nurseries successfully grafted;

NbPtP: Number of plants planted.

\subsection{Statistical Analysis}

Data relating to physico-chemical analyses of soils, vegetative growth parameters and production of rubber plants in bagged nurseries were processed using Excel 2016. Statistica 7.1 software was used for statistical analysis and R 4.1.1 for graphing.

Using Statistica software, one-way analyses of variance (ANOVA) were observed to assess the effects of crop substrates on the physico-chemical properties of soils, vegetative growth and production parameters of rubber plants in bagged nurseries. The mean values were classified according to method of least significant difference $(L S D)$ of Fisher. The probabilities were evaluated $\alpha=5 \%$ threshold.

\section{Results}

\subsection{Effects of Growing Substrates on the Physico-Chemical Properties of the Soil}

The mean values of $\mathrm{pH}$, organic carbon and total nitrogen and $\mathrm{C} / \mathrm{N}$ in soil, at the end of experiment for different crop substrates, are presented in Table 4. With the exception of $\mathrm{N}$ content and $\mathrm{C} / \mathrm{N}$ ratio, the ANOVA of these parameters showed significant effects $(\mathrm{p}<0.05)$ between crop substrates, regardless of the study site. These parameters ( $\mathrm{pH}$ and organic matter) are significantly improved by the compost-based crop substrates compared to initial values at the time of trial and substrates S1 (no fertilizer or control) and S2 (fractional application of urea).

The improvement in chemical parameter values was dependent on the compost dose applied to production of crop substrates. This improved effect was 
Table 4. Average values of Carbon. Nitrogen, $\mathrm{C} / \mathrm{N}$ ratio, Organic matter, Cationic Exchange Capacity, Sum of Exchangeable Bases of crop substrates at Bimbresso and Kimoukro sites.

\begin{tabular}{|c|c|c|c|c|c|c|c|c|c|c|c|c|c|c|}
\hline \multirow{3}{*}{$\begin{array}{l}\text { Substrate } \\
\text { of culture }\end{array}$} & \multirow{2}{*}{\multicolumn{2}{|c|}{$\mathrm{pH}\left(\mathrm{H}_{2} \mathrm{O}\right)$}} & \multicolumn{8}{|c|}{ Soil Organic Matter (MOS) } & \multicolumn{4}{|c|}{ Adsorption complex } \\
\hline & & & \multicolumn{2}{|c|}{$\mathrm{C}(\%)$} & \multicolumn{2}{|c|}{ N (\%) } & \multicolumn{2}{|c|}{$\mathrm{C} / \mathrm{N}$} & \multicolumn{2}{|c|}{ MO (\%) } & \multicolumn{2}{|c|}{ CEC $\left(\mathrm{cmol} \cdot \mathrm{kg}^{-1}\right)$} & \multicolumn{2}{|c|}{ SBE $\left(\mathrm{cmol} \cdot \mathrm{kg}^{-1}\right)$} \\
\hline & BB & $\mathrm{KK}$ & BB & KK & BB & $\mathrm{KK}$ & BB & KK & BB & KK & BB & KK & BB & $\mathrm{KK}$ \\
\hline S1 & $5.9^{\mathrm{ab}}$ & $6.2^{\mathrm{a}}$ & $1.7^{\mathrm{c}}$ & $1.9^{\mathrm{b}}$ & $0.14^{\mathrm{a}}$ & $0.16^{\mathrm{a}}$ & $12.4^{\mathrm{a}}$ & $11.9^{\mathrm{a}}$ & $2.99^{c}$ & $3.29^{\mathrm{b}}$ & $5.6^{\mathrm{b}}$ & $10.4^{\mathrm{a}}$ & $0.87^{\mathrm{c}}$ & $2.31^{\mathrm{c}}$ \\
\hline S2 & $5.0^{\mathrm{b}}$ & $5.1^{\mathrm{b}}$ & $1.6^{\mathrm{c}}$ & $1.8^{\mathrm{b}}$ & $0.13^{\mathrm{a}}$ & $0.14^{\mathrm{a}}$ & $12.7^{\mathrm{a}}$ & $12.8^{\mathrm{a}}$ & $2.86^{\mathrm{c}}$ & $3.10^{\mathrm{b}}$ & $5.6^{\mathrm{b}}$ & $9.2^{\mathrm{a}}$ & $0.60^{\mathrm{c}}$ & $1.66^{\mathrm{c}}$ \\
\hline S3 & $6.1^{\mathrm{ab}}$ & $6.5^{\mathrm{a}}$ & $2.2^{\mathrm{b}}$ & $2.6^{\mathrm{b}}$ & $0.18^{\mathrm{a}}$ & $0.19^{\mathrm{a}}$ & $12.0^{\mathrm{a}}$ & $13.5^{\mathrm{a}}$ & $3.73^{\mathrm{b}}$ & $4.40^{\mathrm{a}}$ & $8.0^{\mathrm{a}}$ & $11.8^{\mathrm{a}}$ & $5.97^{\mathrm{b}}$ & $6.32^{\mathrm{b}}$ \\
\hline S4 & $6.8^{\mathrm{a}}$ & $6.8^{\mathrm{a}}$ & $3.2^{\mathrm{a}}$ & $2.7^{\mathrm{b}}$ & $0.24^{\mathrm{a}}$ & $0.20^{\mathrm{a}}$ & $13.4^{\mathrm{a}}$ & $13.2^{\mathrm{a}}$ & $5.54^{\mathrm{a}}$ & $4.59^{\mathrm{a}}$ & $10.8^{\mathrm{a}}$ & $11.8^{\mathrm{a}}$ & $9.37^{\mathrm{a}}$ & $9.42^{\mathrm{a}}$ \\
\hline S5 & $6.7^{\mathrm{a}}$ & $6.6^{\mathrm{a}}$ & $2.5^{\mathrm{b}}$ & $2.3^{\mathrm{b}}$ & $0.20^{\mathrm{a}}$ & $0.18^{\mathrm{a}}$ & $12.6^{\mathrm{a}}$ & $13.0^{\mathrm{a}}$ & $4.33^{\mathrm{b}}$ & $4.02^{\mathrm{a}}$ & $9.2^{\mathrm{a}}$ & $11.2^{\mathrm{a}}$ & $6.26^{\mathrm{b}}$ & $5.53^{\mathrm{b}}$ \\
\hline S6 & $7.2^{\mathrm{a}}$ & $7.0^{\mathrm{a}}$ & $3.2^{\mathrm{a}}$ & $3.1^{\mathrm{a}}$ & $0.24^{\mathrm{a}}$ & $0.23^{\mathrm{a}}$ & $13.4^{\mathrm{a}}$ & $13.5^{\mathrm{a}}$ & $5.54^{\mathrm{a}}$ & $5.33^{\mathrm{a}}$ & $11.0^{\mathrm{a}}$ & $14.4^{\mathrm{a}}$ & $9.12^{\mathrm{a}}$ & $10.54^{\mathrm{a}}$ \\
\hline $\mathrm{Ti}$ & 5.4 & 6.40 & 1.17 & 2.61 & 0.11 & 0.17 & 10.64 & 15.35 & 2.01 & 4.49 & 8.00 & 13.25 & 0.78 & 7.04 \\
\hline $\mathrm{p}$ & 0.03 & 0.05 & 0.01 & 0.04 & 0.78 & 0.91 & 0.93 & 0.45 & 0.01 & 0.007 & 0.012 & 0.98 & 0.00 & 0.00 \\
\hline MG & 6.30 & 6.37 & 2.40 & 2.40 & 0.20 & 0.18 & 12.75 & 12.98 & 4.20 & 4.12 & 8.36 & 11.46 & 5.36 & 5.96 \\
\hline
\end{tabular}

BB: site of bimbresso; KK: site of kimoukro; C (\%): carbon percentage; $\mathrm{N}(\%)$ : nitrogen percentage; C/N: carbon to nitrogen ratio; MO: organic matter; CEC: cationic exchange capacity; SBE: sum of exchange bases; Ti: initial content; p: probability; MG: general average. 


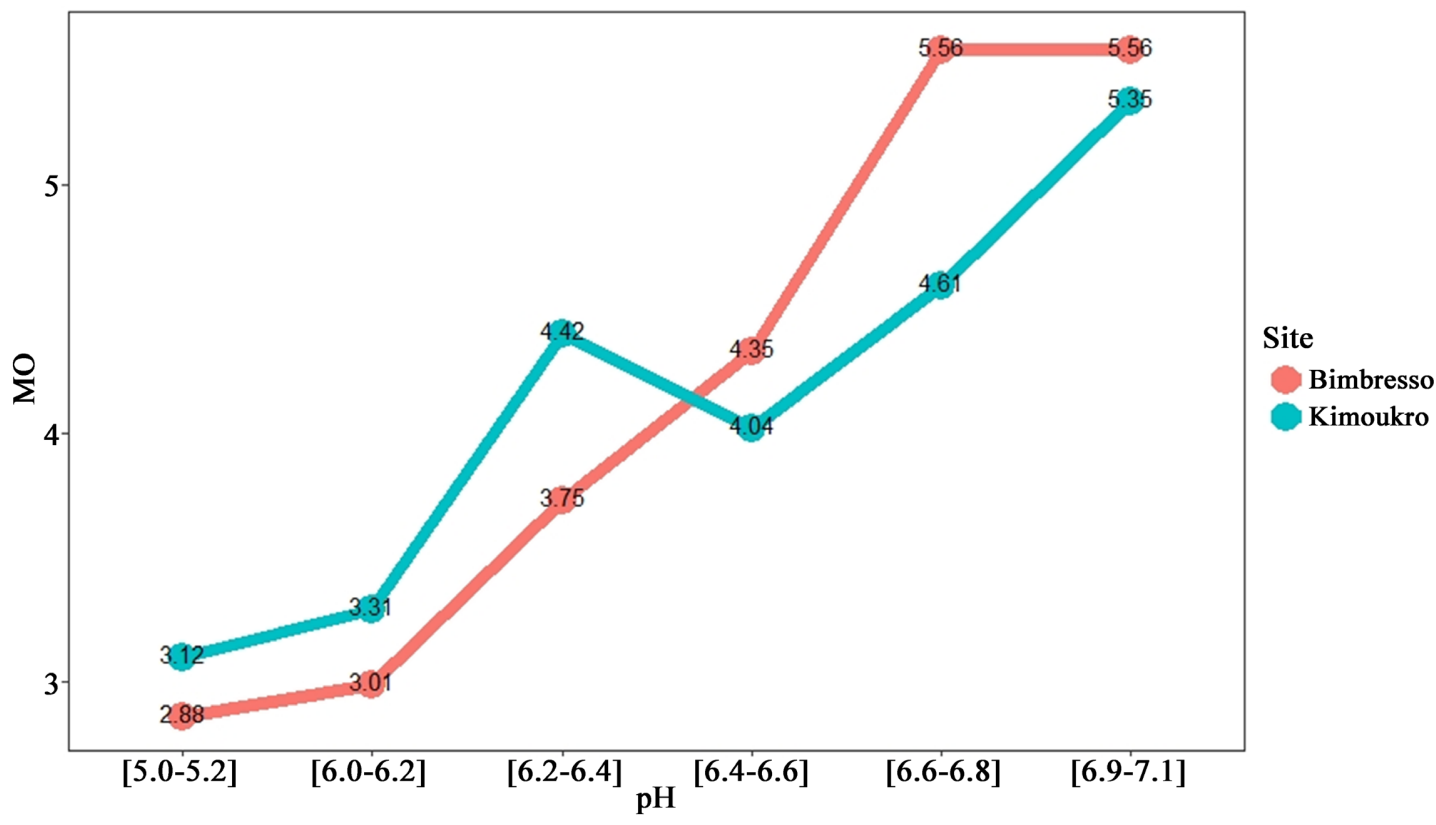

Figure 1. Relationship between soil organic matter (MOS) content and $\mathrm{pH}\left(\mathrm{H}_{2} \mathrm{O}\right)$ at Bimbresso and Kimoukro sites.

Table 5. Average monthly height increase $(\mathrm{H})$ and growth gain compared to control substrate (S1) at Bimbresso site.

\begin{tabular}{cccccccc}
\hline $\begin{array}{c}\text { Substrate } \\
\text { of culture }\end{array}$ & $\Delta \mathrm{H} 1$ & $\Delta \mathrm{H} 2$ & $\Delta \mathrm{H} 3$ & $\Delta \mathrm{H} 4$ & $\Delta \mathrm{H} 5$ & $\Delta$ Hmoy & Gain (\%) \\
\hline S1 (no fertilizer) & $208.29^{\mathrm{b}}$ & $136.25^{\mathrm{bc}}$ & $98.47^{\mathrm{a}}$ & $201.14^{\mathrm{b}}$ & $231.03^{\mathrm{b}}$ & $175.04^{\mathrm{a}}$ & 0.00 \\
S2 & $243.63^{\mathrm{a}}$ & $189.72^{\mathrm{a}}$ & $60.54^{\mathrm{abc}}$ & $237.47^{\mathrm{ab}}$ & $207.25^{\mathrm{b}}$ & $187.72^{\mathrm{a}}$ & 7.25 \\
S3 & $239.45^{\mathrm{a}}$ & $172.00^{\mathrm{ab}}$ & $75.05^{\mathrm{abc}}$ & $291.04^{\mathrm{a}}$ & $306.12^{\mathrm{a}}$ & $216.73^{\mathrm{a}}$ & 23.82 \\
S4 & $224.92^{\mathrm{ab}}$ & $135.53^{\mathrm{bc}}$ & $90.81^{\mathrm{ab}}$ & $274.57^{\mathrm{a}}$ & $300.40^{\mathrm{a}}$ & $205.24^{\mathrm{a}}$ & 17.26 \\
S5 & $206.67^{\mathrm{b}}$ & $149.09^{\mathrm{bc}}$ & $51.26^{\mathrm{bc}}$ & $281.86^{\mathrm{a}}$ & $301.00^{\mathrm{a}}$ & $197.97^{\mathrm{a}}$ & 13.10 \\
S6 & $226.04^{\mathrm{ab}}$ & $126.24^{\mathrm{c}}$ & $48.41^{\mathrm{c}}$ & $241.68^{\mathrm{ab}}$ & $260.54^{\mathrm{ab}}$ & $180.58^{\mathrm{a}}$ & 3.17 \\
MG & 224.83 & 151.47 & 70.76 & 254.63 & 267.72 & 193.88 & \\
p & 0.02 & 0.01 & 0.03 & 0.04 & 0.02 & 0.97 & \\
\hline
\end{tabular}

The letters $\mathrm{a}, \mathrm{b}$ and $\mathrm{c}$ indicate significantly different mean values in the column at the threshold $\alpha=0.05$; p: probability. MG: mean value; $\Delta \mathrm{H}$ : average height increase $\left(\mathrm{mm} \cdot \mathrm{month}^{-1}\right)$ for two observation stages; $\Delta$ Hmoy: average monthly increase in height $\left(\mathrm{mm} \cdot \mathrm{month}^{-1}\right)$ during the trial; Gain (\%): Gain in height growth compared to control substrate (S1).

On the site of Bimbresso (Table 5 and Table 6), average values ranged from 175.04 to $216.73 \mathrm{~mm} \cdot \mathrm{month}^{-1}$ (height) and 1.57 to $2.00 \mathrm{~mm} \cdot \mathrm{month}^{-1}$ (collar diameter), respectively for substrates S1 (control, no fertilizer) and S3 $\left(27 \mathrm{t} \cdot \mathrm{ha}^{-1}\right.$ or $300 \mathrm{~g}$ of compost per plant). Compost-based substrates allow significant growth gains in height and collar diameter compared to control substrate (S1). The growth gains were $13.10 \%$ to $23.82 \%$, respectively for substrates S5, S4 and S3 for 
height growth and $12.34 \%$ to $27.88 \%$ respectively for substrates S6, S4, S5 and S3 at the collar diameter level.

However, the application of compost based on chicken droppings induced a better vegetative growth of the plants, but at high doses (especially substrate S6) a depressed growth retardation in height and collar diameter was observed compared to the plants in substrate S2 (fractional application of urea). On the site of Kimoukro (Table 7 and Table 8), the average monthly increases ranged

Table 6. Average monthly increase in collar diameter $(\mathrm{C})$ and growth gain compared to the control substrate (S1) at Bimbresso site.

\begin{tabular}{cccccccc}
\hline $\begin{array}{c}\text { Substrate } \\
\text { of culture }\end{array}$ & $\Delta \mathrm{C} 1$ & $\Delta \mathrm{C} 2$ & $\Delta \mathrm{C} 3$ & $\Delta \mathrm{C} 4$ & $\Delta \mathrm{C} 5$ & $\Delta \mathrm{C}$ moy & Gain (\%) \\
\hline S1 (no fertilizer) & $1.46^{\mathrm{b}}$ & $1.17^{\mathrm{c}}$ & $1.60^{\mathrm{a}}$ & $1.33^{\mathrm{a}}$ & $2.27^{\mathrm{bc}}$ & $1.57^{\mathrm{a}}$ & 0.00 \\
S2 & $1.40^{\mathrm{b}}$ & $1.84^{\mathrm{ab}}$ & $1.86^{\mathrm{a}}$ & $1.29^{\mathrm{a}}$ & $2.04^{\mathrm{c}}$ & $1.69^{\mathrm{a}}$ & 7.63 \\
S3 & $1.96^{\mathrm{a}}$ & $2.17^{\mathrm{a}}$ & $1.65^{\mathrm{a}}$ & $1.38^{\mathrm{a}}$ & $2.86^{\mathrm{a}}$ & $2.00^{\mathrm{a}}$ & 27.88 \\
S4 & $1.69^{\mathrm{ab}}$ & $1.76^{\mathrm{ab}}$ & $1.88^{\mathrm{a}}$ & $1.88^{\mathrm{a}}$ & $2.55^{\mathrm{ab}}$ & $1.95^{\mathrm{a}}$ & 24.71 \\
S5 & $1.48^{\mathrm{b}}$ & $1.71^{\mathrm{b}}$ & $1.70^{\mathrm{a}}$ & $1.60^{\mathrm{a}}$ & $2.80^{\mathrm{a}}$ & $1.86^{\mathrm{a}}$ & 18.50 \\
S6 & $1.60^{\mathrm{ab}}$ & $1.60^{\mathrm{bc}}$ & $1.41^{\mathrm{a}}$ & $1.43^{\mathrm{a}}$ & $2.76^{\mathrm{ab}}$ & $1.76^{\mathrm{a}}$ & 12.34 \\
$\mathrm{MG}$ & 1.60 & 1.71 & 1.68 & 1.49 & 2.55 & 1.80 & \\
$\mathrm{p}$ & 0.00 & 0.01 & 0.91 & 0.77 & 0.02 & 0.68 & \\
\hline
\end{tabular}

The letters $\mathrm{a}, \mathrm{b}$ and $\mathrm{c}$ indicate significantly different mean values in the column at the threshold $\alpha=0.05$; p: probability; MG: mean value; $\Delta \mathrm{C}$ : average diameter increase $\left(\mathrm{mm} \cdot \mathrm{month}^{-1}\right)$ for two observation stages; $\Delta$ Cmoy: average monthly increase in diameter $\left(\mathrm{mm} \cdot \mathrm{month}^{-1}\right)$ during the trial; Gain (\%): Gain in collar diameter growth compared to control substrate (S1).

Table 7. Average monthly height increase $(\mathrm{H})$ and growth gain compared to control substrate (S1) at Kimoukro site.

\begin{tabular}{cccccccc}
\hline $\begin{array}{c}\text { Substrate } \\
\text { of culture }\end{array}$ & $\Delta \mathrm{H} 1$ & $\Delta \mathrm{H} 2$ & $\Delta \mathrm{H} 3$ & $\Delta \mathrm{H} 4$ & $\Delta \mathrm{H} 5$ & $\Delta \mathrm{Hmoy}$ & Gain (\%) \\
\hline S1 (no fertilizer) & $110.75^{\mathrm{a}}$ & $104.44^{\mathrm{a}}$ & $101.84^{\mathrm{a}}$ & $128.15^{\mathrm{a}}$ & $158.15^{\mathrm{a}}$ & $120.67^{\mathrm{a}}$ & 0.00 \\
S2 & $101.92^{\mathrm{a}}$ & $124.48^{\mathrm{a}}$ & $113.71^{\mathrm{a}}$ & $175.63^{\mathrm{a}}$ & $205.63^{\mathrm{a}}$ & $144.27^{\mathrm{a}}$ & 19.57 \\
S3 & $107.50^{\mathrm{a}}$ & $94.69^{\mathrm{a}}$ & $112.59^{\mathrm{a}}$ & $162.05^{\mathrm{a}}$ & $192.06^{\mathrm{a}}$ & $133.78^{\mathrm{a}}$ & 10.87 \\
S4 & $110.20^{\mathrm{a}}$ & $66.57^{\mathrm{a}}$ & $101.63^{\mathrm{a}}$ & $139.66^{\mathrm{a}}$ & $169.66^{\mathrm{a}}$ & $117.54^{\mathrm{a}}$ & -02.59 \\
S5 & $115.34^{\mathrm{a}}$ & $97.53^{\mathrm{a}}$ & $119.70^{\mathrm{a}}$ & $200.18^{\mathrm{a}}$ & $204.19^{\mathrm{a}}$ & $147.39^{\mathrm{a}}$ & 22.14 \\
S6 & $75.48^{\mathrm{a}}$ & $75.81^{\mathrm{a}}$ & $105.44^{\mathrm{a}}$ & $153.84^{\mathrm{a}}$ & $133.84^{\mathrm{a}}$ & $108.88^{\mathrm{a}}$ & -09.77 \\
MG & 103.53 & 93.92 & 109.15 & 159.92 & 177.26 & 128.76 & \\
p & 0.64 & 0.54 & 0.94 & 0.88 & 0.67 & 0.38 & \\
\hline
\end{tabular}

The letter a indicate not significantly different mean values in the column at the threshold $\alpha=0.05$; p: probability. MG: mean value; $\Delta \mathrm{H}$ : average height increase $\left(\mathrm{mm} \cdot \mathrm{month}^{-1}\right)$ for two observation stages; $\Delta$ Hmoy: average monthly increase in height $\left(\mathrm{mm} \cdot \mathrm{month}^{-1}\right.$ ) during the trial; Gain (\%): gain in height growth compared to control substrate (S1). 
Table 8. Average monthly increase in collar diameter (C) and growth gain compared to control substrate (S1) at Kimoukro site.

\begin{tabular}{cccccccc}
\hline $\begin{array}{c}\text { Substrate } \\
\text { of culture }\end{array}$ & $\Delta \mathrm{C} 1$ & $\Delta \mathrm{C} 2$ & $\Delta \mathrm{C} 3$ & $\Delta \mathrm{C} 4$ & $\Delta \mathrm{C} 5$ & $\Delta \mathrm{C}$ moy & Gain (\%) \\
\hline S1 (Control) & $0.79^{\mathrm{a}}$ & $0.91^{\mathrm{a}}$ & $0.64^{\mathrm{a}}$ & $1.76^{\mathrm{a}}$ & $1.14^{\mathrm{a}}$ & $1.05^{\mathrm{a}}$ & 0.00 \\
S2 & $0.95^{\mathrm{a}}$ & $0.78^{\mathrm{a}}$ & $0.62^{\mathrm{a}}$ & $1.92^{\mathrm{a}}$ & $1.27^{\mathrm{a}}$ & $1.11^{\mathrm{a}}$ & 5.70 \\
S3 & $1.09^{\mathrm{a}}$ & $0.78^{\mathrm{a}}$ & $0.87^{\mathrm{a}}$ & $1.27^{\mathrm{a}}$ & $1.43^{\mathrm{a}}$ & $1.09^{\mathrm{a}}$ & 3.84 \\
S4 & $0.90^{\mathrm{a}}$ & $0.62^{\mathrm{a}}$ & $1.09^{\mathrm{a}}$ & $1.24^{\mathrm{a}}$ & $1.28^{\mathrm{a}}$ & $1.03^{\mathrm{a}}$ & -1.97 \\
S5 & $1.04^{\mathrm{a}}$ & $0.62^{\mathrm{a}}$ & $1.02^{\mathrm{a}}$ & $1.42^{\mathrm{a}}$ & $1.45^{\mathrm{a}}$ & $1.12^{\mathrm{a}}$ & 6.69 \\
S6 & $0.65^{\mathrm{a}}$ & $0.51^{\mathrm{a}}$ & $0.87^{\mathrm{a}}$ & $1.76^{\mathrm{a}}$ & $1.11^{\mathrm{a}}$ & $0.98^{\mathrm{a}}$ & -6.48 \\
MG & 0.90 & 0.70 & 0.85 & 1.56 & 1.28 & 1.06 & \\
p & 0.40 & 0.68 & 0.91 & 0.63 & 0.79 & 0.72 & \\
\hline
\end{tabular}

The letter a indicate not significantly different mean values in the column at the threshold $\alpha=0.05$; p: probability. MG: mean value; $\Delta \mathrm{C}$ : average diameter increase $\left(\mathrm{mm} \cdot \mathrm{month}^{-1}\right.$ ) for two observation stages; $\Delta$ Cmoy: average monthly increase in diameter $\left(\mathrm{mm} \cdot \mathrm{month}^{-1}\right)$ during the trial; Gain (\%): gain in collar diameter growth compared to control substrate (S1).

from 108.88 (S6) to $147.39 \mathrm{~mm} \cdot \mathrm{month}^{-1}$ (S5) in plant height and from 0.98 (S6) to $1.12 \mathrm{~mm} \cdot \mathrm{month}^{-1}$ (S5) in collar diameter.

However, low growth gains in height and collar diameter compared to control substrate (S1, no fertilizer) were observed with substrates S2, S3 and S5. These growth gains ranged from $3.84 \%$ to $6.69 \%$, respectively for S3, S2 and S5 substrates for collar diameter and from $10.87 \%$ to $22.14 \%$, respectively for S3, S2 and S5 substrates for height. In addition, retardation of rubber plants growth in nursery was observed in substrates with a high dose of compost (substrates S4 and S6). This growth retardation were as high as $-9.77 \%$ in plant height for substrate S6.

\subsection{Grafting Success Rate}

Forty-two (42) days after grafting, the grafting success rates ranged from $92.61 \%$ to $100 \%$ respectively for substrates S2 and S4 at Bimbresso and from $81.86 \%$ (substrate S4) to $96.59 \%$ (substrate S5) at the site of Kimoukro. The lowest grafting success rates were observed with crop substrates S2 (92.61\%) and S4 (81.86\%), respectively at the site of Bimbresso and Kimoukro (Figure 2). The grafting success rate of the crop substrates S1, S3, S4, S5 and S6 at the site of Bimbresso, and S1, S2, S3 and S5 at Kimoukro site were statistically equivalent ( $\mathrm{p}$ $\geq 0.05$ ).

\section{Discussion}

\subsection{Effects of Crop Substrates on the Chemical and Physico-Chemical Properties of Soils}

The significant effects of compost-based substrates on soil chemical parameters 




Figure 2. Grafting success rate as a function of culture substrates at the Bimbresso and Kimoukro sites.

at Bimbresso and at Kimoukro sites have been shown by the improvement of $\mathrm{pH}$ $\left(\mathrm{H}_{2} \mathrm{O}\right)$, soil organic matter, exchangeable bases, $\mathrm{CEC}$, exceptionally at high doses of compost. Several works, such as those of Useni, Bouadou, Sikuzani and Biaou [23] [24] [25] [26] have shown that the application of organic fertilizers to the soil improves its physical chemical and biological properties.

The compost used, through its good physical quality (more than $90 \%$ fine elements, $\varnothing \leq 10 \mathrm{~mm}$ ) and its fertilizing value of an acceptable level, ensures a high availability of nutrients, as well as after cultivation. In fact, organic matter, which is essential for soil fertility, produces humus. When it decomposes, it not only releases the nitrogenous matter essential for plant development, but also plays a major role in maintaining a favourable soil structure. Therefore, its use in the manufacture of crop substrates has created better growing and nutrition conditions for rubber plants in bagged nurseries.

For $\mathrm{pH}\left(\mathrm{H}_{2} \mathrm{O}\right)$ of soil, the application of compost has resulted in a decrease in soil acidity. This increase in soil $\mathrm{pH}$ would be linked, on the one hand, to the buffering effect of organic matter and, on the other hand, to high cation exchange capacity (CEC) of bivalent ions ( $\mathrm{Ca}$ and $\mathrm{Mg}$ ). These cations, despite their removal by rubber plants, are in sufficient quantities in the substrates, notably $\mathrm{S} 4$ and $\mathrm{S} 6$ to neutralise the $\mathrm{H}^{+}$and $\mathrm{Al}^{3+}$ ions responsible for acidity [11] [27]. According to Boyer [28], the application of organic matter to the soil can complex the $\mathrm{Al}^{3+}$ ions responsible for soil acidity and making them inactive. These ions, which are strongly retained, pass with some difficulty into the soil solution. This also indicates the decrease in soil acidity observed in the compost-based sub- 
strates, particularly the high-dose compost substrates (S4 and S6).

An increase in soil acidity was observed in the substrate S2 as a result of fractional application of urea $(46 \% \mathrm{~N})$. This increase in soil acidity of this substrate corroborates the results of earlier work by Kaho [29], which revealed the acidifying effect of chemical fertilizers on Altisols and Ultisols in Ghana and Nigeria. Brady [30] reported that most complete fertilizers unless specially treated tend to form an acid residue in soils. This is mainly due to the influence of some of nitrogen carriers, especially those that supply ammonia and produce ammonium ions by hydrolysis.

However, ammonium ions, presented as potential sources of soil acidity, also behave as an antagonistic cation of $\mathrm{K}^{+}, \mathrm{Ca}^{2+}$ and $\mathrm{Mg}^{2+}$; excesses of $\mathrm{NH}^{4+}$ can cause a deficiency of these elements $(\mathrm{K}, \mathrm{Ca}$ and $\mathrm{Mg})$ and conversely, an addition of $\mathrm{Ca}$ reduces the toxicity of $\mathrm{NH}^{4+}$ [31]. Chemical amendments also gradually increase soil acidity, which consequently has a negative impact on the development of soil microorganisms [32].

Results also showed a significant improvement in soil organic matter content and cation exchange capacity (CEC) with the use of compost. According to Abobi [11], the increase in CEC is due to organic amendments, which would have affected the phenomena of fixation of exchangeable cations on the adsorbent complex of soils. The increase in CEC is more dependent on the increase in organic matter than on the low clay fraction found in the soils, and indirectly on the $\mathrm{pH}$ through its reaction behaviour with these two colloids (clays and organic matter).

Cation exchange capacity is related to the clay-humus complexes formed by humus and mineral particles, via the cations $\mathrm{Ca}^{2+}, \mathrm{Fe}^{2+}$ and $\mathrm{Al}^{3+}$, which are responsible for improving the soil properties that the compost helps to form [33].

In addition, Huber and Schaub [34] report that soil organic matter content would be a determining factor in the CEC value. Other studies have also shown strong correlations between $\mathrm{CEC}$, organic carbon content and $\mathrm{pH}\left(\mathrm{H}_{2} \mathrm{O}\right)$ of the soil [35] [36]. Several authors have also demonstrated the increase in CEC following the application of composts [36] [37] [38]. High levels of organic matter result in higher CEC and the soil retains nutrients to make them available to plants for growth [39].

Regarding soil nitrogen content, no substrate effects have been observed at any site. However, compared to initial soil content, the $\mathrm{N}$ values recorded at the end of trial show a slight increase in compost-based substrates, especially substrates with a high dose of compost (S4 and S6). N'Dienor [40] indicated that composts contain relatively little nitrogen $(0.5 \%$ to $0.6 \%)$ according to the basic components), their quantitative application can provide the necessary additional nitrogen and start its dynamics in the soil. According to Nyembo [41], organic manures release nitrogen in a form that is assimilable by the plant and their actions are slow and progressive. The fertilizing value of the nitrogen contained in the compost is therefore generally low, but should not be neglected in the case of 
high inputs.

\subsection{Effects of Crop Substrates on Vegetative Growth Parameters}

Regarding the growth of rubber plants in bagged nursery, the compost-based substrates performed better than the control substrate (S1, no fertilizer), with statistically significant differences for vegetative growth parameters and grafting success rate.

At Bimbresso, the average values of the monthly increase in collar diameter $(\Delta C)$, most important parameter in the management of rubber plants in nursery, were significantly higher for plants of compost-based substrates compared with plants of control substrate (S1). Moreover, these values are even higher than that observed by Compagnon [21], which are of order of $1.5 \mathrm{~mm} \cdot \mathrm{month}^{-1}$ on average. At Kimoukro site, the substrate S5 significantly improved the vegetative growth of the plants compared to the control substrate S1.

This difference in growth observed with compogst-based substrates would be linked, firstly to the compost maturity obtained and, secondly to its richness in fertilizing elements. Nutrients from the mineralisation of chicken droppings and dry Panicum maximum straw must have enriched the soil and contributed favourably to the development of rubber plants in nursery compared to plants of control substrate (S1) on these two sites. This confirms the observations made by Amadji [42] after using compost enriched with chicken droppings for cabbage production on sandy soil and Essehi [13] on the impact of organic fertilization on some soil characteristics and on rubber tree growth parameters during the installation phase in Bonoua, southern Côte d'Ivoire.

These results would indicate that the nutrients, specifically nitrogen, phosphorus and potassium, were more available in the compost-based crop substrates than other substrates (S1 and S2). It was noted that independently of the site, a delay in plant growth was observed in substrates containing high doses of compost.

Compared to the control substrate S1, these growth retardation rates were as much as $-9.77 \%$ in height and $-6.48 \%$ in collar diameter of plants at Kimoukro site. This observed retardation could be the consequence of the alkalinizing action of compost on the soil, which considerably reduces soil acidity, as mentioned above. Compared to initial values, soil $\mathrm{pH}$ increased from 1.4 to 1.8 unit at Bimbresso and from 0.4 to 0.6 unit at Kimoukro, respectively, for S4 and S6 substrates.

This increase in $\mathrm{pH}$ to neutrality level was to a certain extent prejudicial to the growth of rubber plants in nursery. In fact, the results of pot cultivation, Compagnon [21], indicate that rubber tree is a very hardy acidophilic plant, capable of adapting to variations in soil $\mathrm{pH}\left(\mathrm{H}_{2} \mathrm{O}\right)$. However, rubber tree growth is inhibited on soils with a $\mathrm{pH}$ above 6.0. This phenomenon has been well demonstrated in experiments with potted crops where chlorosis and growth failure were already evident at $\mathrm{pH} 6.5$ [43]. 
Furthermore, Ferrand [44], made the same observation using the practice of burning in the valorisation of forest soils intended for the rubber trees in nursery. According to this author, the pile of ash left after burning the wood stumps locally alkalinises the soil and makes stains on which the young rubber trees grow with difficulty. On the same topic, Compagnon [45] mentioned that $\mathrm{pH}$ values most frequently recorded for satisfactory rubber tree growth are between 4 and 6.5. He stated that young rubber trees are very sensitive to excess alkalinity. The response curves of height growth as a function of soil $\mathrm{pH}$ obtained in this experiment seem to explain this phenomenon. Indeed, they show good vegetative growth of rubber plants in nursery at acidic $\mathrm{pH}$ levels (between 4.5 and 6.0).

The grafting success rate does not differ significantly according to treatment and study site. These results suggest that parameter graft success in Hevea brasiliensis is not influenced by application of fertilizers (compost or fractional application of urea). However, Ondo [46] concluded that in tropical climates, the number of successful grafts and the grafting success rate are influenced differently, depending on the type of rubber tree clones, method of rootstock transplanting (in bags or in ground), month of grafting and origin of the graft wood.

\section{Conclusions}

At the end of this study, we can retain that compost increases, in proportion to doses applied, the soil's levels of soil organic matter, nitrogen, the sum of exchangeable bases (SBE) and cation exchange capacity (CEC).

For soil $\mathrm{pH}$, compost input resulted in a decrease in soil acidity. Compost-based substrates performed better than S1 (no fertiliser) and S2 (fractional application of urea) substrates with statistically significant differences for vegetative growth parameters. However, high doses of compost $\left(54 \mathrm{t} \cdot \mathrm{ha}^{-1}\right)$ tend to raise the soil $\mathrm{pH}$ (towards neutrality), which strongly depreciates the vegetative growth of rubber plants in bagged nurseries. The production of rubber plants material was optimal with compost doses of $27 \mathrm{t} \cdot \mathrm{ha}^{-1}$ (at Bimbresso site, south of Côte d'Ivoire) and $27 \mathrm{t} \cdot \mathrm{ha}^{-1}$ combined with the fractional application of urea (at Kimoukro site, centre of Côte d'Ivoire)

However, our results also showed that water availability for rubber plants in bagged nurseries was a limiting factor, especially in Kimoukro, an area described as marginal for rubber cultivation. Therefore, a factorial experimentation that would make it possible to define the best combination of fertilization and irrigation would be conceivable. In addition, the economic profitability of this organic fertilizer linked to the costs of compost production (purchase of inputs, cost of technical equipment and labour) remains to be evaluated.

\section{Acknowledgements}

The authors would like to thank Interprofessional Funds for Research and Agricultural Council (FIRCA) and Association of Rubber Professionals and Manu- 
facturers (APROMAC) in Côte d'Ivoire for their financial support for this study.

\section{Conflicts of Interest}

The authors declare no conflicts of interest regarding the publication of this paper.

\section{References}

[1] Canh, T.V. (1999) Recherche pour le secteur hévéicole en Côte d'Ivoire. Plantation, Recherche, Développement, 6, 102-106. https://agritrop.cirad.fr/392314

[2] APROMAC (2020) Association des Professionnels et Manufacturiers du Caoutchouc naturel de Côte d'Ivoire.

https://www.linfodrome.com/economie/64019-la-cote-divoire-seul-pays-non-asiati que-dans-le-top-5-mondial

[3] Eschbach, J.M. and Tonnelier, M. (1984) Influence de la méthode de la stimulation, de la concentration du stimulant et de la fréquence de son application sur la production du clone GT1 en Côte d'Ivoire. CR Coll. Expl. Physiol. Amél. Hévéa, IRCA-CIRAD, ed., Montpellier, 295-306.

[4] Prévot, J.C., Jacob, J.L., Lacrotte, R., Vidal, A., Serres, E., Eschbach, J.M. and Gigault, J. (1986) Physiological Parameters of Latex from Hevea brasiliensis. Their Use in the Study of the Laticiferous System. Typology of Functioning Production Metabolism. Effects of Stimulation. Proceedings of the IRRDB Rubber Physiology and Exploitation Meeting, Hainan, 9-12 December 1986, 136-157.

[5] Lacrotte, R. (1991) Études des relations entre la teneur en sucres du latex et la production. Approche des mécanismes du chargement en saccharose des laticifères d'Hevea brasiliensis Muell. Arg. Thèse de doctorat d'Université de Montpellier II.

[6] Obouayeba, S. (2005) Contribution à la détermination de la maturité physiologique de l'écorce pour la mise en saignée d'Hevea brasiliensis Müell. Arg. (Euphorbiaceae): Normes d'ouverture. Thèse de Doctorat Unique, UFR Biosciences, Université de Cocody-Abidjan (Côte d'Ivoire).

[7] Kéli, Z.J., Kpolo., D.M., Déa, G.B., Boa, D. and Allet-Don A. (1997) L’hévéaculture en Côte d'Ivoire: Situation actuelle et perspectives. Plantations, Recherches, Développement, 4, 5-14.

[8] Mougo, N.H.L. (2012) Analyse et estimation des pertes de plants dans le cycle d'une pépinière stumps: Cas de l'Unité Agricole Intégrée de la SAPH à Bongo. Mémoire de fin d'études, Diplôme D'agronomie Approfondie (DAA), École Supérieure d'Agronomie (ESA), Institut National Polytechnique Félix Houphouët Boigny (INPHB) de Yamoussoukro, Côte d'Ivoire.

[9] Ganry, F. and Badiane, A. (1998) La valorisation agricole des fumiers et des composts en Afrique soudano-sahélienne: Diagnostic et perspectives. Cirad-Agritrop, Agriculture et Développement, 18, 73-80. https://agritrop.cirad.fr/390389

[10] Compaoré, E., Nanéma, L.S., Bonkoungou, S. and Sedogo, M.P. (2010) Evaluation de la qualité de composts de déchets urbains solides de la ville de Bobo-Dioulasso, Burkina Faso pour une utilisation efficiente en agriculture. Journal of Applied Biosciences, 33, 2076-2083. https://www.m.elewa.org/JABS/2010/33/4.pdf

[11] Abobi, A.H.D., Angui, T.K.P. and Kouadio, Y.J. (2014) Influence de la fertilisation à base des coques de cacao sur les paramètres chimiques d'un ferralsol et sur la croissance du maïs (Zea mays L.) à Oumé, Côte d'Ivoire. Journal of Applied Biosciences, 82, 7359-7371. https://doi.org/10.4314/jab.v82i1.4 
[12] Koulibaly, B., Dakuo, D., Ouattara, A., Traoré, O., Lompo, F., Zombré, P.N. and Yao-kouamé, A. (2015) Effets de l'association du compost et de la fumure minérale sur la productivité d'un système de culture à base de cotonnier et de maïs au Burkina Faso. Tropicultura, 33, 125-134. https://www.tropicultura.org/text/v33n2/125.pdf

[13] Essehi, J.L., Gala, B.T.J., Kassin, K.E., Soumahin, E.F., Okoma, K.M., Obouayeba, S. and Yao-Kouamé, A. (2016) Impact de la fertilisation organique sur quelques caractéristiques du sol et les paramètres de croissance de l'hévéa (Hevea brasiliensis Müll Arg.) en phase d'installation à Bonoua dans le Sud de la Côte d'Ivoire. International Journal of Innovation and Scientific Research, 27, 143-154.

http://www.issr-journals.org/links/papers.php?.journal=ijisr\&application=pdf\&articl e=IJISR-16-207-03

[14] Kitabala, M.A., Tshala, U.J., Kalenda, M.A., Tshijika, I.M. and Mufind, K.M. (2016) Effets de différentes doses de compost sur la production et la rentabilité de la tomate (Lycopersicon esculentum Mill) dans la ville de Kolwezi. Province du Lualaba (RD Congo). Journal of Applied Biosciences, 102, 9669-9679.

[15] Biekré, A., Tié, B.T. and Dogbo, D.O. (2018) Caractéristiques physico-chimiques des composts à base de sous-produits de ferme de Songon en Côte d'Ivoire. International Journal of Biological and Chemical Sciences, 12, 596-609.

https://doi.org/10.4314/ijbcs.v12i1.45

[16] Avenard, J.M., Girard, G., Sircoulou, J., Toucheboeuf, P., Guillaumet, J.C., Adjanohoun, E. and Perraud, A. (1971) Le milieu naturel de la Côte d'Ivoire. ORSTOM, Paris.

[17] Brou, T.Y. (2005) Climat, mutations socio-économiques et paysage en Côte d'Ivoire. Mémoire de synthèse des activités scientifiques présentées en vue de l'obtention de l'habilitation à diriger des recherches, Université des Sciences et Technologies de lilles, France.

[18] Bakayoko, S., Kouadio, K.K.H., Soro, D., Tschannen, A., Nindjin, C., Dao, D. and Girardi, O. (2012) Rendements en tubercules frais et teneurs en matière sèche de soixante-dix nouvelles variétés de manioc (Manihot esculenta Crantz) cultivées dans le centre de la Côte d'Ivoire. Journal of Animal and Plant Sciences, 14, 1961-1977. https://m.elewa.org/JAPS/2012/14.2/5.pdf

[19] WRB (2006) World Reference Base for Soil Resources. A Framework for International Classification, Correlation and Communication. IUSS-ISRIC-FAO, Rome.

[20] Penot, M.E. (2001) Stratégies paysannes et évolution des savoirs: L'hévéaculture agro-forestière indonésienne. Thèse présentée pour obtenir le grade de Docteur de l'université Montpellier, France.

[21] Compagnon, P. (1986) Le caoutchouc naturel. Maisonneuse \& Larose, Paris.

[22] Elabo, A.E.A., Gnagne, Y.M., Assi, M.G., Okoma, K.M. and Obouayeba, S. (2014) Amélioration du taux de réussite au champ des stumps d’hévéa de 10 mois. Fiche technique CNRA-HEVEA.

[23] Sikuzani, Y.U., Chukiyabo, K.M., Tshomba, K.J., Muyambo, M.E., Kapalanga, K.P. Ntumba, N.F., Kasangij, A.K.P., Kyungu, K., Baboy, L.L., Nyembo, K.L. and Mpundu, M.M. (2013) Utilisation des déchets humains recyclés pour l'augmentation de la production du maïs (Zea mays L.) sur un ferralsol du sud-est de la RD Congo. Journal of Applied Biosciences, 66, 5070-5081.

https://www.m.elewa.org/JABS/2013/66/5.pdf https://doi.org/10.4314/jab.v66i0.95005

[24] Bouadou oi, B.F., Brahima, K., Yao K., Yao-Kouamé, A. and Oikeh, O.S. (2014) Tropical Cambisol as Affected by Sugarcane (Sacharum officinarum L.) Foam and Inorganic Fertilizer. American Journal of Experimental Agriculture, 4, 732-745. 
https://doi.org/10.9734/AJEA/2014/7082

[25] Sikuzani, Y.U., Ilunga, G.M., Mulembo, T.M., Katombe, B.N., Lwalaba, W.L.J., Lukangila, B.A.M., Lubobo, K.A. and Longanza, B.L. (2014) Amélioration de la qualité des sols acides de Lubumbashi (Katanga, RD Congo) par l'application de différents niveaux de compost de fumiers de poules. Journal of Applied Biosciences, 77, 6523-6533. https://doi.org/10.4314/jab.v77i1.3

[26] Biaou, O.D.B., Saidou, A., Bachabi, F.-X., Padonou, G.E. and Balogoun, I. (2017) Effet de l'apport de différents types d'engrais organiques sur la fertilité du sol et la production de la carotte (Daucus carota L.) sur un sol ferrallitique au sud Bénin. International Journal of Biological and Chemical Sciences, 11, 2315-2326. https://doi.org/10.4314/ijbcs.v11i5.29

[27] Djébré, L.S.M. (2008) Valorisation agronomique des incuits de chaux du traitement des eaux de consommation, Mémoire de DEA. Université Nangui Abrogoua (Abidjan), Côte d'Ivoire.

[28] Boyer, J. (1982) Les sols ferralitiques: Facteurs de fertilité et utilisation des sols. Tome X. Initiation-Documentations Techniques, 52, ORSTOM, Paris.

[29] Kaho, F., Yemefack, M. and Quashie-Sam, J. (2002) Soil Fertility Changes under Leucaena leucocephala Woodlot and Their Consequences on the Succeeding Crop in the Humid Forest Zone of Ghana. Nigerian Journal of Soil Research, 3, 39-44.

[30] Brady, N.C. (1974) The Nature and Properties of Soils. 8th Edition, MacMillan Publishing, New York.

[31] Heller, R. (1984) Physiologie végétale. 1. Nutrition. 3è Edition, Masson, Paris.

[32] Leclerc, B. (2001) Guide des matières organiques. Tome 2, ITAB, Paris.

[33] Charland, M., Cantin, S., St Pierre, M.A. and Côté, L. (2001) Recherche sur les avantages à utiliser le compost. Dossier CRIQ.

[34] Huber, G. and Schaub, C. (2011) La fertilité des sols: L'importance de la matière organique. Agricultures et Territoires.

https://agriculture-de-conservation.com/La-fertilite-des-sols-l-importance.html

[35] Willet, I.R. (1994) Physical and Chemical Constraints to Sustainable Soil Use under Rainfed Conditions in the Humid Tropics of Southeast Asia. In: Syers, J.K. and Rimmer, D.L., Eds., Soil Science and Sustainable Land Management in the Tropics, CABI Publishing, Wallingford, 234-247.

[36] Mbonigaba, M.J.J. (2007) Etude de l'impact des composts à base de biomasse végétale sur la dynamique des indicateurs physico-chimiques, chimiques et microbiologiques de la fertilité des sols: Application sur trois sols acides tropicaux du Rwanda. Thèse de doctorat, FUSAGx, Gembloux, Belgique.

[37] Epstein, E. and Wu, N. (1994) The SAMM Compost Pilot Project Agricultural Study. Final Report E\&A Environmental Consultants Inc., Canton.

[38] Clément, M.F. and N'Dayegamiye, A. (2009) Rotation dans la culture de pomme de terre: bilans humiques et logiciel de calcul. CRAAQ, Colloque sur la pomme de terre, Québec.

[39] Anne, W. and Jean D. (2009) Amendement et fertilisation. Guide de gestion globale de la ferme maraîchère biologique et diversifiée, Module 7.

[40] N’Dienor, M. (2006) Fertilité et gestion de la fertilisation dans les systèmes maraîchers périurbains des pays en développement: Intérêts et limites de la valorisation agricole des déchets urbains dans ces systèmes, cas de l'agglomération d'Antanarivo (Madagascar). Thèse de Doctorat, Université d'Antanarivo, Madagascar.

[41] Nyembo, K.L., Useni, S.Y., Chinawej, M.M. and Baboy, L.L. (2014) Amélioration 
des propriétés physiques et chimiques des sols sous l'apport combiné des biodéchets et des engrais minéraux et influence sur le comportement du maïs (Zea mays L. var Unilu). Journal of Applied Biosciences, 74, 6121-6130.

https://doi.org/10.4314/jab.v74i1.7

[42] Amadji, G.L., Saïdou, A. and Chitou, L. (2009) Recycling of Residues in Compost to Improve Coastal Sandy Soil Properties and Cabbage Shoot Yield in Bénin. International Journal of Biological and Chemical Sciences, 3, 192-202.

https://doi.org/10.4314/ijbcs.v3i2.44497

[43] Rhines, C.E., Mc Gavack, J. and Linke, C.J. (1952) Mineral Nutrition of Hevea brasiliensis. Rubber Age (N.Y.), 70, 467-474.

[44] Ferrand, M. (1944) Phytotechnie de l'Hevea brasiliensis: Botanique, amélioration, culture et exploitation, Librairie agricole de la Maison Rustique.

[45] Compagnon, P. (1962) The Mineral Nutrition of Hevea. Revue Générale du Caoutchouc, 39, 1105-1132.

[46] Ondo, O.P., Kebangoye, H.-S., Medza, M.S.D., Nguema, N.P., Kevers, C. and Dommes, J. (2018) Facteurs permettant d'améliorer la réussite au greffage des clones GT 1 et PB 217 d'Hevea brasiliensis (H.B.K.) (Muell. Arg) dans les conditions climatiques du nord Gabon. Journal of Animal \& Plant Sciences, 35, 5749-5762.

https://m.elewa.org/Journals/wp-content/uploads/2018/03/5.Ondo-Abstract-JAPSVol.35.pdf 